\title{
Autocrine activity of soluble Flt-1 controls endothelial cell function and angiogenesis
}

\author{
Vascular Cell 3:15 I DOI: 10.1186/2045-824X-3-15 I C Li et al.; licensee Publiverse Online S.R.L. 2011 \\ Received: 4 Apr 2011 I Accepted: 13 Apr 2011 I Published: 13 Apr 2011 \\ Ahmad Shakil $^{+}$, Hewett Peter $\mathrm{W}^{+}$, Al-Ani Bahjat, Sissaoui Samir, Fujisawa Takeshi, Cudmore Melissa J, \\ Ahmed Asif ${ }^{@}$ \\ ${ }^{+}$Contributed equally ${ }^{@}$ Corresponding author
}

\begin{abstract}
Background

The negative feedback system is an important physiological regulatory mechanism controlling angiogenesis. Soluble vascular endothelial growth factor (VEGF) receptor-1 (sFlt-1), acts as a potent endogenous soluble inhibitor of VEGFand placenta growth factor (PlGF)-mediated biological function and can also form dominant-negative complexes with competent full-length VEGF receptors.
\end{abstract}

\section{Methods and results}

Systemic overexpression of VEGF-A in mice resulted in significantly elevated circulating sFlt-1. In addition, stimulation of human umbilical vein endothelial cells (HUVEC) with VEGF-A, induced a five-fold increase in sFlt-1 mRNA, a timedependent significant increase in the release of sFlt- 1 into the culture medium and activation of the $f l t-1$ gene promoter. This response was dependent on VEGF receptor-2 (VEGFR-2) and pho sphoinositide-3'-kinase signalling. siRNAmediated knockdown of sFlt-1 in HUVEC stimulated the activation of endothelial nitric oxide synthase, increased basal and VEGF-induced cell migration and enhanced endothelial tube formation on growth factor reduced Matrigel. In contrast, adenoviral overexpression of sFlt-1 suppressed phosphorylation of VEGFR-2 at tyrosine 951 and ERK-1/-2 MAPK and reduced HUVEC proliferation. Preeclampsia is associated with elevated placental and systemic sFlt- 1 . Phosphorylation of VEGFR-2 tyrosine 951 was greatly reduced in placenta from preeclamptic patients compared to gestationally-matched normal placenta.

\section{Conclusion}

These results show that endothelial sFlt-1 expression is regulated by VEGF and acts as an autocrine regulator of endothelial cell function.

\section{Background}

Vascular endothelial growth factor-A (VEGF-A) is a multifunctional cytokine induced by hypoxic stress [ 1]. It plays a pivotal role in many aspects of embryonic cardiovascular development, including formation of blood vessels, cardiac morphogenesis, and development of the nervous system [2-6]. Loss and gain of function studies in mice indicate that VEGF-A levels have to be maintained within a narrow range to ensure proper cardiovascular development and embryo survival [ 7-9]. It has been shown that the effects of VEGF-A can be deleterious if uncontrolled. Over-expression of VEGF in experimental animals increases the leakiness of blood vessels, which may lead to severe edema, loss of limb and death [ 10,11]. Excess VEGF-A expression in skeletal muscle results in the induction of vascular tumors (hemangiomas) [ 12- 14], whereas loss of VEGF-A activity due to increased production of its natural antagonist, sFlt-1 (soluble VEGF receptor-1/sVEGFR-1), as in preeclampsia, reduces angiogenesis [ 15]. Thus, homeostasis requires mechanisms to regulate the functional activity of VEGF-A.

Soluble Flt-1 is generated by alternative splicing of the fms-like tyrosine kinase ( $f t-1)$ gene [ 16 ], and binds to all isoforms of VEGF-A and placenta growth factor (PlGF) with high affinity [ 16,17]. It acts as a potent soluble inhibitor of both VEGF-A and PIGF-mediated biological activities [18] and can also form dominant-negative complexes with competent full-length VEGF receptors [ 16]. In pregnancies complicated with preeclampsia, sFlt-1 levels are elevated [ 15, 19-21]. Maternal serum levels of sFlt-1 are elevated five weeks prior to the onset of preeclampsia [ 22], supporting the premise that sFlt-1 is a key factor responsible for the clinical manifestation of this disorder [ 23]. The demonstration 
that sFlt-1 is fundamental to the clinical onset of preeclampsia [ 24] highlights the importance of understanding the intracellular mechanism underlying its regulation and release in endothelial cells. Recently it was shown that autocrine VEGF signaling is required for vascular homeostasis [ 25]. Here we demonstrate that endothelial sFlt-1 expression is regulated by VEGF and sFlt-1 is an autocrine regulator of endothelial cell function.

\section{Materials and methods}

\section{Reagents}

Recombinant growth factors were purchased from RELIATech (Brauschweig, Germany). Rabbit polyclonal antibodies against phospho- endothelial nitric oxide synthase (eNOS) at serine-1177 (p-eNOS ${ }^{\text {Ser1177 }}$ ), phospho-ERK-1/-2 MAPK and phospho-VEGF receptor-2 (VEGFR-2) tyrosine-951 antibodies were purchased from Calbiochem (Nottingham, UK). Small inhibitory RNAs (siRNA) and oligonucleotide primers were purchased from Eurogentec (Southampton, UK). Luciferase reporter assay and cDNA synthesis kits were from Promega (Southampton, UK). All other cell culture reagents and chemicals were obtained from Sigma Aldrich (Poole, UK).

\section{Placental tissues}

Human placental tissue was obtained from normal pregnancies and gestationally-matched pregnancies complicated by preeclampsia. Preeclampsia was defined as blood pressure $>140 / 90 \mathrm{~mm} \mathrm{Hg}$ on at least two consecutive measurements and proteinuria of at least $300 \mathrm{mg}$ per 24 hours. Informed consent was obtained from the patients and the study had the approval of the South Birmingham Ethical Committee (Birmingham, UK).

\section{Cell Culture}

Primary human umbilical vein endothelial cells (HUVEC) were isolated and cultured as described [ 26]. Cells were used at passage two or three for experiments and serum-starved in endothelial cell serum-free medium (Gibco-BRL, UK) supplemented with $0.2 \%$ bovine serum albumin for 24 hours prior to stimulation.

\section{Adenoviral gene transfer}

The recombinant, replication-deficient adenoviruses encoding sFlt-1 (Ad-sFlt-1) VEGF (Ad-VEGF) and PTEN (AdPTEN) were used as described previously [ 27-29].

\section{Quantitative Real-Time PCR}

Sample preparation and real-time PCR was performed as described previously [ 30]. Briefly, mRNA was prepared using TRIzol and DNase-1 digestion/purification on RNAeasy columns (Qiagen), and reverse transcribed with the cDNA Synthesis Kit (Promega). Triplicate cDNA samples and standards were amplified in SensiMix containing SYBR green (Quantace) with primers specific for sFlt-1 [ 31]. The mean threshold cycle (CT) was normalized to $\beta$-actin and expressed relative to control.

\section{siRNA knock-down of sFlt-1}

Two siRNA sequences to the unique 3' sequence of sFlt-1 (sFlt-1 A sense: 5'-TAACAGUUGUCUCAUAUCAtt-3' and antisense: 5'-UGAUAUGAGACAACUGUUAtt-3'; sFlt-1 B sense: 5'-UCUCGGAUCUCCAAAUUUAtt-3' and antisense 5'-UAAAUUUGGAGAUCCGAGAtt-3') were designed using the Dharmacon siDESIGN tool [ 32]. HUVEC ( $1 \times 10$ ${ }^{6}$ cells) were electroporated with $\sim 3 \mu \mathrm{g}$ of sFlt-1, or a universal control siRNA (Dharmacon) using the HUVEC kit II and Amaxa nucleofector (Amaxa GmbH, Cologne, Germany) as described [ 30].

\section{Transduction of chimeric VEGF Receptors in HUVEC}

A chimeric VEGF/epidermal growth factor (EGF) receptor comprising the intracellular and transmembrane domains of VEGFR-2 fused to the extracellular domain of the human EGF receptor [ 33]. EGF does not bind to VEGF receptors, therefore, it does not activate the endogenous VEGF receptors. EGDR and its tyrosine-to-phenylalanine mutants (EGDRY951F) were generated and cloned into the pMMP retroviral vector, and retrovirus-containing cell supernatant was harvested and used immediately to infect HUVEC [ 33]. Following 16 hours of incubation, the medium was replaced with fresh growth medium and the HUVEC were used 48 hours after infection.

\section{Nitric oxide (NO) Release}

Total NO in conditioned media was assayed as nitrite, the stable breakdown product of NO, using a Sievers NO chemiluminescence analyzer (Analytix, Sunderland, UK) as described previously [ 33]. 
The formation of capillary-like structures was examined on growth factor-reduced Matrigel in 24-well plates as described previously [ 33]. Tube formation was quantified by measuring the total tube length in five random x200 power fields per well using a Nikon phase-contrast inverted microscope with Image ProPlus image analysis software (Media Cybernetics, Silver Spring, USA). Mean total tube length was calculated from three independent experiments performed in duplicate.

\section{flt-1 gene promoter activity assay}

A $1.3 \mathrm{~Kb}$ fragment of the human $f t-1$ gene corresponding to -1214 to +155 bp relative to the first exon in the pGL2 luciferase vector (Promega) was used to determine $f t-1$ promoter activity [ 34]. Briefly, porcine aortic endothelial cells (PAEC) were transfected with the $f l t-1$ promoter-reporter construct using Exgen 500 (Fermentas, UK) and the cell lysates assayed as described previously [34].

\section{Western Blotting}

Cells lysates were immunoblotted as described previously [ 33]. Membranes were probed with rabbit polyclonal antibodies against phospho-eNOS-Ser ${ }^{1177}$, anti-ERK-1/-2 or anti-VEGFR-2 phosphotyrosine-951 at $4^{\circ} \mathrm{C}$ overnight. Proteins were visualised using the ECL detection kit (Amersham-Pharmacia, UK).

\section{sFlt-1 ELISA}

Soluble Flt-1 (sFlt-1) levels in culture supernatants were measured as previously described [ 30].

\section{Immunohistochemistry}

Formalin-fixed, paraffin-embedded tissues were used for immunohistochemistry as previously described [ 15].

\section{Statistical analysis}

All data are expressed as mean \pm SEM. Statistical comparisons were performed using one-way ANOVA followed by the Student-Newman-Keuls test as appropriate. Statistical significance was set at a value of $\mathrm{p}<0.05$.

\section{Results and Discussion}

\section{VEGF-A stimulates sFlt-1 release}

To evaluate the capacity of VEGF-A to regulate the secretion of its negative regulator, sFlt-1, HUVEC were incubated with VEGF-A and the conditioned media assayed for sFlt-1 by ELISA. VEGF-A stimulated a concentration and time dependent increase in the release of sFlt- 1 from HUVEC that reached a maximum at $20 \mathrm{ng} / \mathrm{ml}$ and 48 hours, respectively (Figure $1 \mathrm{a}$ and $1 \mathrm{~b}$ ). Consistent with these findings, qPCR revealed a greater than five-fold increase in sFlt-1 mRNA after 22 hours of VEGF-A stimulation (Figure 1c). In addition, VEGF-A induced $f t$ - 1 gene promoter activity in porcine aortic endothelial cells transfected with a $f t-1$ promoter luciferase construct (Figure 1d). Incubation of cells with cycloheximide abrogated the VEGF-A induced response (Figure 1e), which coupled with the fact that there is a negligible release with VEGF-A after two hours of stimulation, indicates that sFlt-1 secretion is due to de novo protein synthesis and not release from intracellular vesicles. Adenoviral-mediated overexpression of VEGF-A in mice caused an eight-fold increase in circulating sFlt-1 levels (Figure 1f), demonstrating, in vivo, that an increase in VEGF-A results in a concomitant rise in circulating sFlt-1 levels, presumably to compensate for elevated VEGF bioactivity.

\section{Figure 1}


a

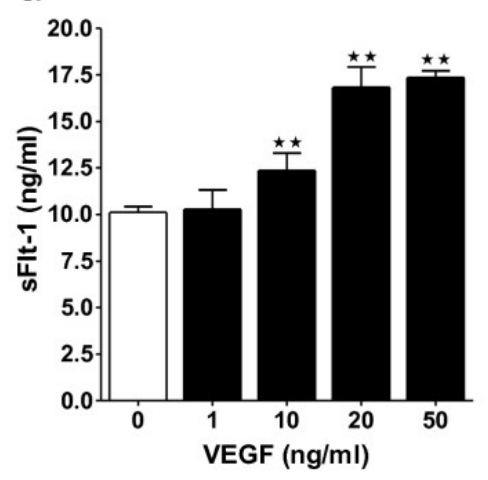

d

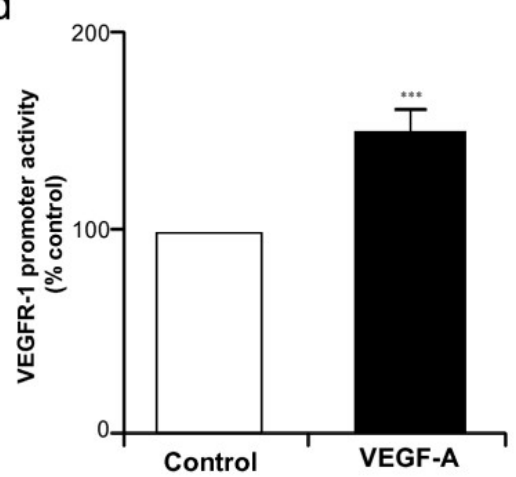

b

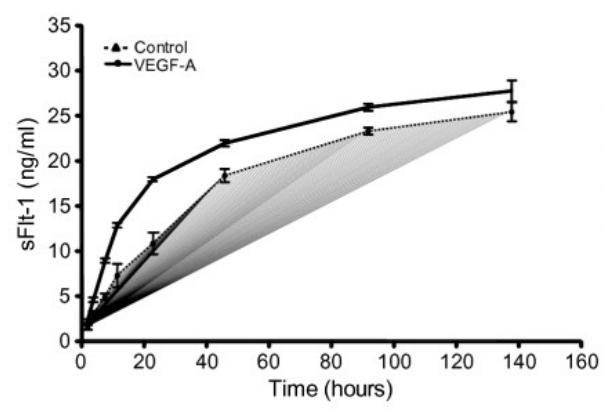

e

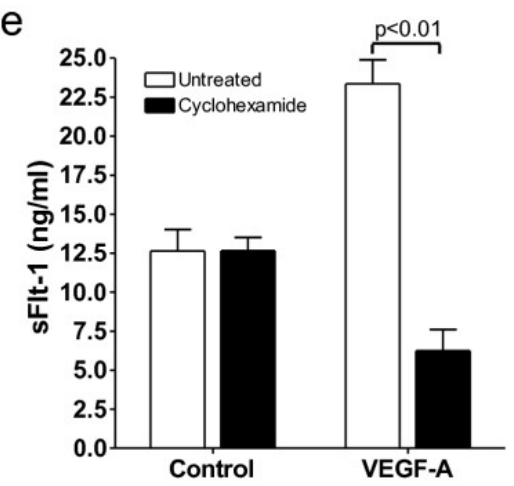

C

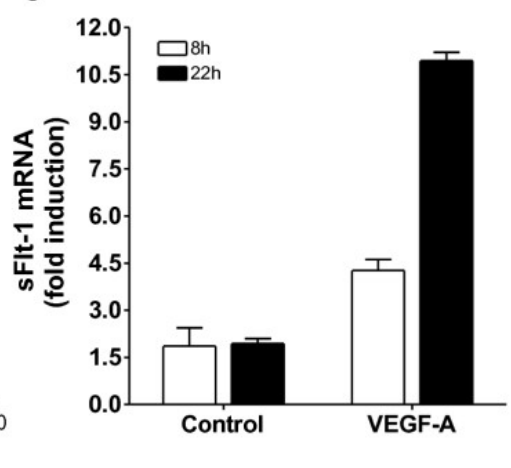

f

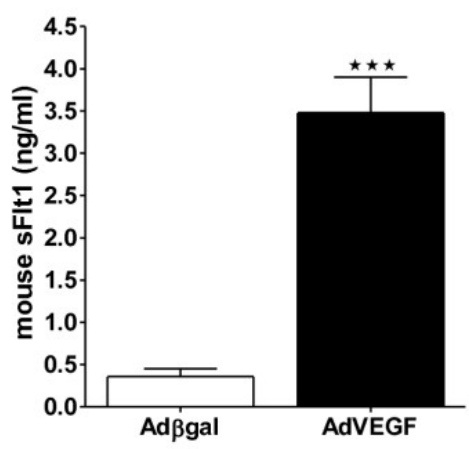

VEGF stimulates sFlt-1 release from endothelial cells in vitro, and in vivo. (a)VEGF stimulated sFlt-1 release from HUVEC in a concentration-dependent manner. sFlt-1 was measured, in the culture medium, by ELISA, following a 24-hour incubation. (b)Time course of VEGF $(20 \mathrm{ng} / \mathrm{ml})$ induced sFlt-1 release from HUVEC. (c)VEGF induced an increase in sFlt-1 mRNA levels in HUVEC as determined by qPCR and, (d) $f t-1$ promoter activity in porcine aortic endothelial cells by luciferase assay. (e)Cyclohexamide $(10 \mu \mathrm{g} / \mathrm{ml})$ inhibits VEGF-induced sFlt-1 protein synthesis after 24 hours of treatment. (f)Mouse plasma levels of sFlt-1 five days post intravenous injection with an adenovirus encoding VEGF (Ad-VEGF) or control (Ad- $\beta$ gal). Data are expressed as mean $( \pm$ SEM) or representative of three or more independent experiments performed in triplicate. $* * P<0.01 ; * * P<0.001$ vs. control.

\section{Activation of VEGFR-2, mediates the release of sFlt-1}

To identify the VEGF receptors involved in the release of sFlt-1, HUVEC were stimulated with either VEGF-A (binds VEGFR-1 and VEGFR-2), or PIGF-1 (binds VEGFR-1) or VEGF-E (binds VEGFR-2). PlGF-1 showed no effect on sFlt1 release, whereas VEGF-E stimulated similar levels of sFlt-1 release to those induced by VEGF-A (Figure 2a), suggesting that release of sFlt-1 is mediated by VEGFR-2. Preincubation of endothelial cells with SU1498, a VEGFR-2 selective inhibitor, blocked the VEGF-A induced sFlt-1 release (Figure 2b), confirming the importance of this receptor for the response.

\section{Figure 2}


a

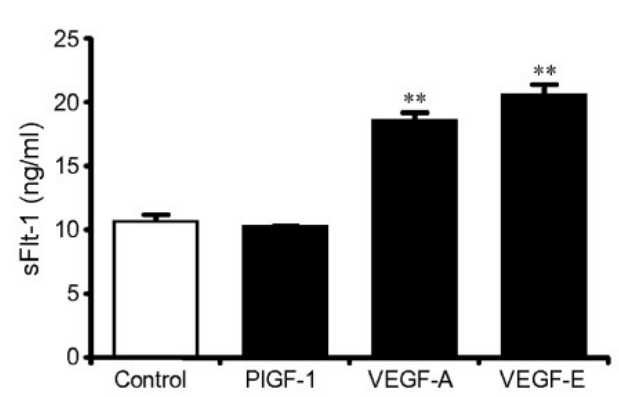

b

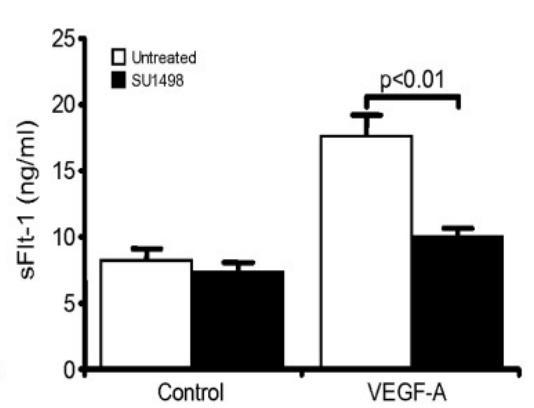

C

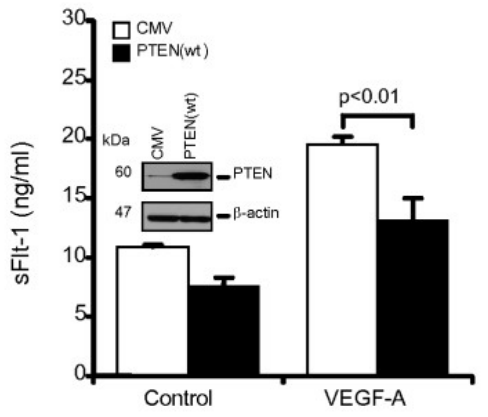

d

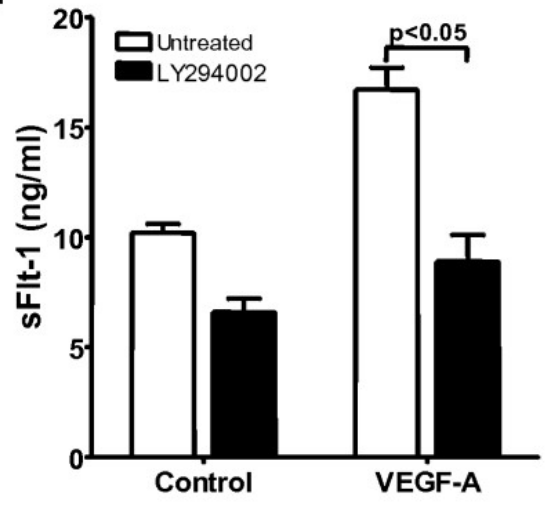

e

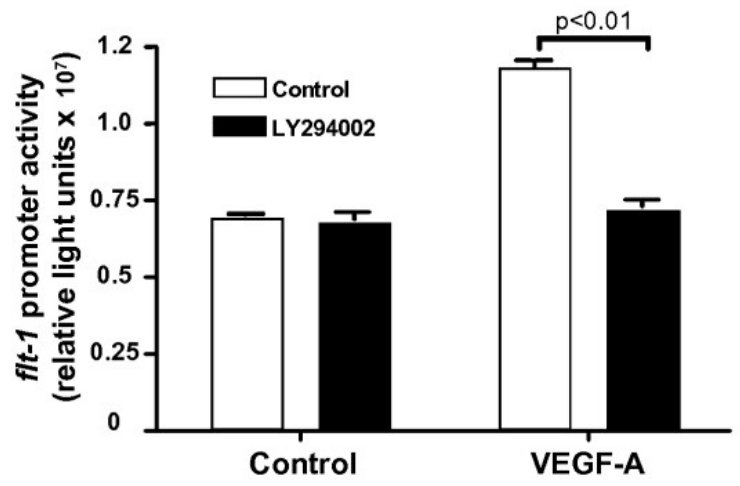

VEGF-A-induced sFlt-1 release requires VEGFR-2 and the PI3K pathway. (a)sFlt-1 release from HUVEC 24 hours after incubation with PlGF-1 (20 ng/ml), VEGF-A (20 ng/ml) and VEGF-E (20 ng/ml). (b)sFlt-1 release from HUVEC after incubation with SU1498 $(10 \mu \mathrm{M})$, a VEGFR-2 tyrosine kinase inhibitor, prior to addition of VEGF-A $(20 \mathrm{ng} / \mathrm{ml})$ for 24 hours. (c)sFlt-1 release from HUVEC infected with an adenovirus encoding PTEN (PTEN (wt)) or control adenovirus (CMV) prior to stimulation with VEGF-A $(20 \mathrm{ng} / \mathrm{ml})$ for 24 hours. Western blot demonstrating decreased PTEN expression in HUVEC infected with Ad-PTEN(wt) compared with Ad-CMV control (insert). (d)sFlt1 release from HUVEC after incubation with LY294002 $(10 \mu \mathrm{M})$, a PI3K inhibitor, prior to addition of VEGF-A (20 $\mathrm{ng} / \mathrm{ml}$ ) for 24 hours. (e)LY294002 prevented the VEGF-A-induced flt-1 promoter activity in porcine aortic endothelial cells, assayed by luciferase reporter assay. Data are expressed as mean $( \pm$ SEM) or representative of three or more independent experiments performed in triplicate. $* * P<0.01$ vs. control.

\section{VEGF stimulated sFlt-1 production, is mediated via PI3K}

To investigate the role of the PI3K pathway in VEGF-A-induced sFlt-1 release, PI3K activity was inhibited through overexpression of PTEN (Phosphatase and Tensin homolog deleted on chromosome Ten), which dephosphorylates phosphatidylinositol 3,4,5-triphosphate and has been shown to reduce VEGF-mediated signaling and cellular function [ 28,35 ]. HUVEC were infected overnight with an adenovirus encoding PTEN (PTEN(wt)) or a control adenovirus (CMV) and stimulated with VEGF-A for 24 hours. Inhibition of PI3K activity by PTEN overexpression led to a significant decrease in sFlt-1 release (Figure 2c). Furthermore, pre-incubation of HUVEC with LY294002, a pharmacological PI3K inhibitor, also attenuated the VEGF mediated release of sFlt-1 (Figure $2 \mathrm{~d}$ ) and of $f t-1$ gene promoter activity (Figure 2e).

\section{Loss of sFlt-1 promotes angiogenesis}

Adenoviral-mediated overexpression of sFlt-1 in HUVEC inhibited endothelial cell proliferation (Figure 3a) and MAP kinase ERK-1/-2 phosphorylation (Figure 3ainsert). Subsequently, to test whether knockdown of sFlt-1 would promote endothelial cell proliferation, HUVEC were transfected with two synthetic siRNA sequences targeted to the unique carboxyl-terminus region of sFlt-1. sFlt-1 siRNA transfection resulted in a substantial reduction in the release of sFlt-1 from HUVEC after 24 hours (Figure 3b). Endothelial cell proliferation was significantly increased (Figure 3c) and interestingly, sFlt-1 knockdown also led to a concomitant increase in VEGFR-2 phosphorylation at tyrosine 951 (Y951) (Figure 3d). In addition, sFlt-1 siRNA increased both basal and VEGF-A-mediated endothelial cell migration (Figure 4a) and tube formation on Matrigel (Figure 4b and 4c). VEGF stimulates eNOS activity and NO release [ 23, 36] to mediate angiogenesis [ 33,37 , thus we predicted that loss of sFlt-1 would increase eNOS phosphorylation in HUVEC.

Phosphorylation of eNOS (ser1177) was significantly increased in cells lacking sFlt-1 (Figure 4d). These data provide direct evidence that sFlt-1 is itself a negative regulator of endothelial function. It is likely that sFlt-1 sequesters VEGF and PIGF to maintain a physiological steady state until angiogenesis is required, at which point this system must be overridden. 
Figure 3

a

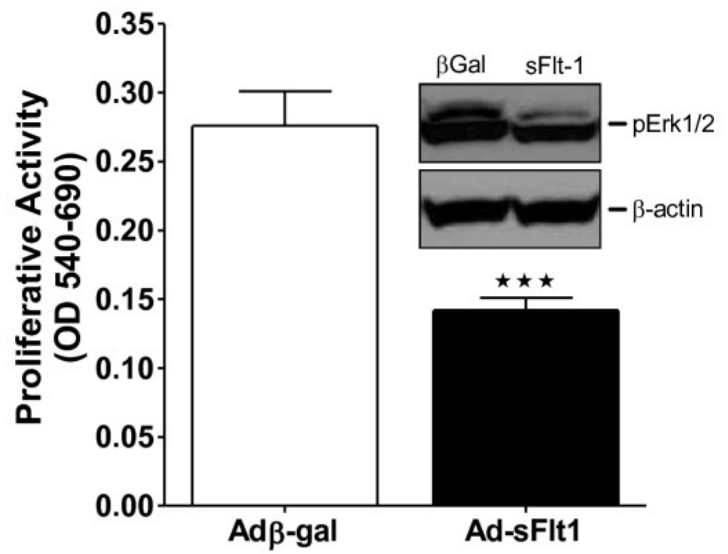

C

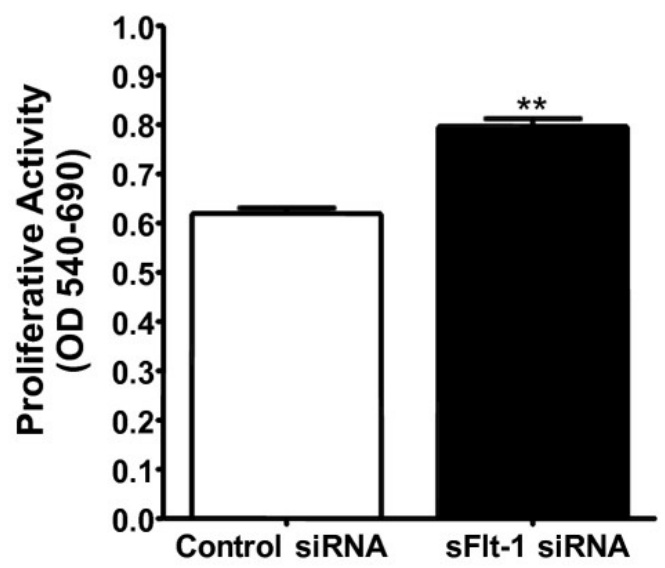

b

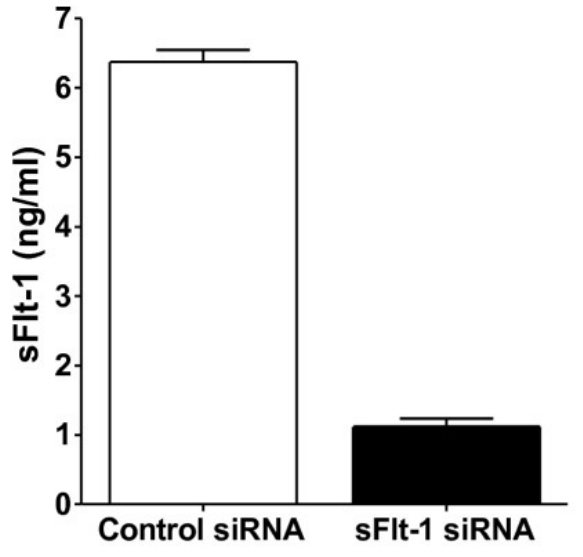

d

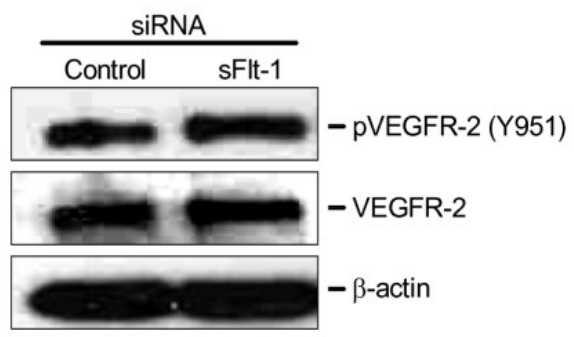

sFlt-1 inhibits endothelial cell proliferation and VEGF receptor phosphorylation. (a)Cell proliferation after 48 hours of treatment in HUVEC infected with an adenovirus encoding sFlt-1 (Ad-sFlt1) or $\beta$-galactosidase control (Ad- $\beta$ Gal). Western blot demonstrating decreased Erk1/2 phosphorylation in HUVEC infected with Ad-sFlt-1 compared with Ad$\beta$-gal control (insert). (b)Dramatic reduction of sFlt-1 release from HUVEC 24 hours after transfection with sFlt-1 siRNA. (c)Cell proliferation after 48 hours in sFlt-1 siRNA transfected HUVEC. (d)Western blot showing VEGF receptor-2 (VEGFR-2) phosphorylation at tyrosine 951 in HUVEC transfected with sFlt-1, or control siRNA. VEGFR-2 and $\beta$-actin were used as a loading control. Data are expressed as mean $( \pm$ SEM) or representative of three or more independent experiments performed in triplicate. $* * P<0.01 \mathrm{vs}$. control.

\section{Figure 4}


a

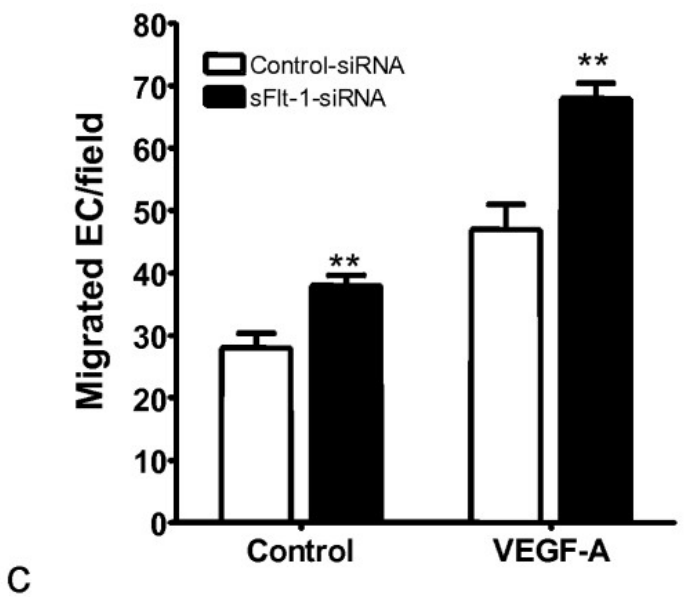

C

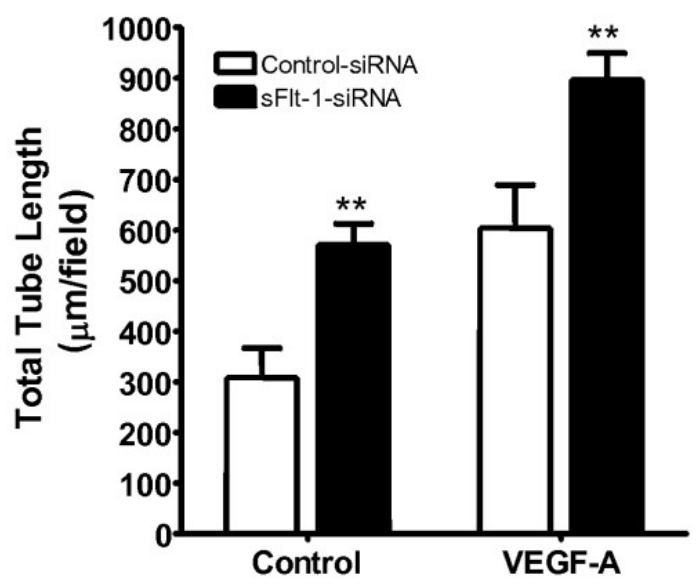

b

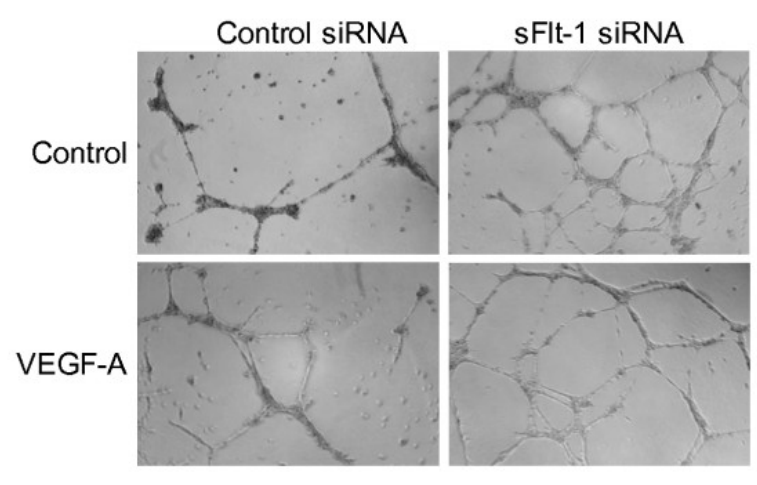

d

Loss of sFlt-1 enhances angiogenesis and eNOS phoshorylation. (a)VEGF $(20 \mathrm{ng} / \mathrm{ml})$ induced an increase in cell migration of HUVEC transfected with sFlt-1 siRNA compared with control siRNA using a modified Boyden chamber assay. (b)VEGF-induced capillary-like tube formation and (c)quantification of mean total tube length per field of view after six hours treatment in HUVEC transfected with sFlt-1 siRNA or control. (d)Representative Western blot showing eNOS phosphorylation at serine 1177 (p-eNOS (S1177)) in HUVEC transfected with soluble (sFlt-1) or control siRNA. $\beta$-actin was used as a loading control. Data are expressed as mean $( \pm$ SEM) or representative of three or more independent experiments performed in triplicate. ${ }^{* *} P<0.01$ vs. control.

\section{Excess SFIt-1 inhibits VEGFR-2 Y951 phosphorylation}

Activation of VEGFR-2 leads to an increase in eNOS expression and activation,[ 38] which is essential for neovascularisation [ 37]. A recent study showed that mutation of VEGFR-2 Y951 to phenylalanine caused a significant reduction in VEGF-induced angiogenesis [ 33]. As preeclampsia is associated with elevated placental [ 15] and circulating [ 22] sFlt-1 and placental sFlt-1 inhibits angiogenesis [ 15], we speculated that elevated free sFlt-1 would lead to a reduction of VEGFR-2 phosphorylation in preeclamptic placenta. Using the EGFR-chimeric receptor system we show that mutation of Y951 to phenylalanine resulted in over 50\% reduction in NO release (Figure 5a) and overexpression of sFlt-1 in endothelial cells abrogated phosphorylation of VEGFR-2 Y951 (Figure 5b). To assess whether VEGFR-2 phosphorylation was reduced in preeclamptic placenta, that express elevated sFlt-1, we undertook immunohistochemical analysis for phospho-VEGFR-2 Y951. Overall, phosphorylation of VEGFR-2 Y951 was greatly reduced in the preeclamptic placenta compared to gestationally-matched, normal placenta (Figure $5 \mathrm{c}$ ). Together, these findings indicate that increased levels of sFlt-1 have a negative effect on VEGFR-2 tyrosine phosphorylation, which in turn would lead to concomitant inhibition of downstream function and signaling and compromise maternal vascular homeostasis and placental angiogenesis.

\section{Figure 5}




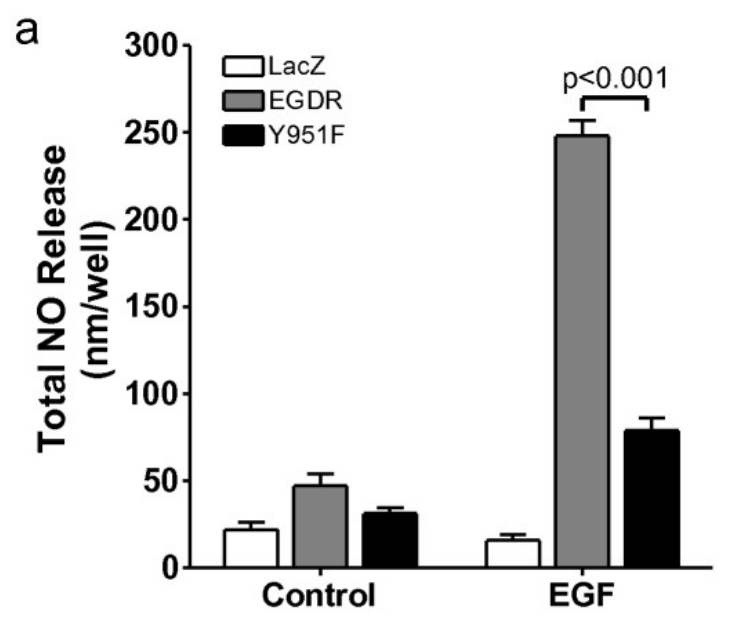

b

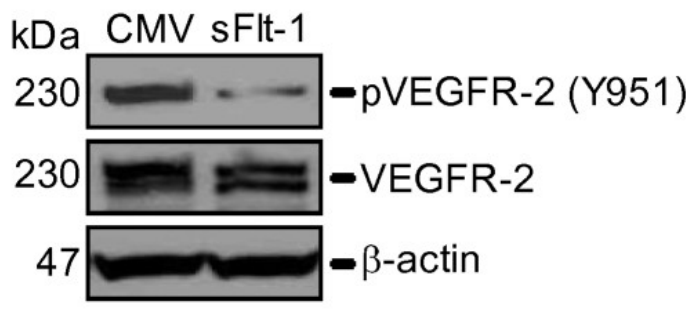

C

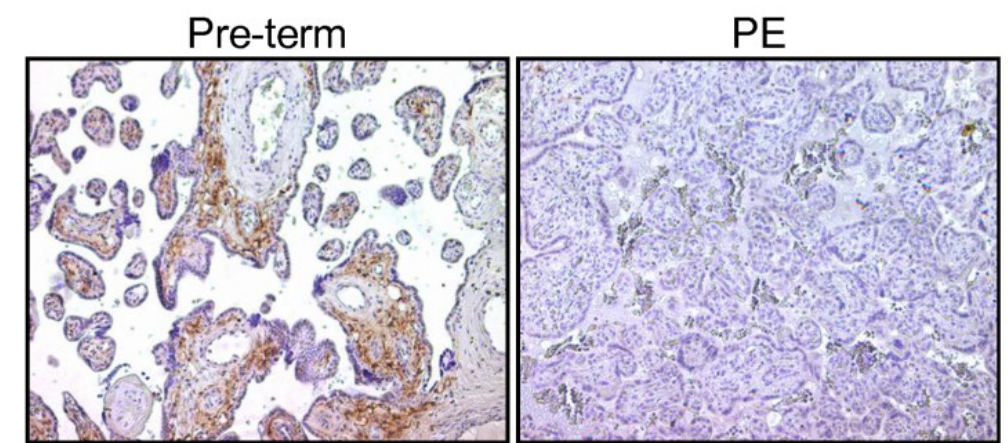

pVEGFR-2 (Y951)

Excess sFlt-1 inhibits VEGF receptor phosphorylation at tyrosine 951. (a)Nitric oxide (NO) release from HUVEC overexpressing chimeric EGF receptor/VEGFR-2 constructs (EGDR) and EGDR with a mutated Y951 (Y951F), following stimulation with EGF $(10 \mathrm{ng} / \mathrm{ml})$ for one hour. NO was measured in cell supernatants using a Sievers chemiluminescent NO analyzer and background subtracted. (b)Western blot showing VEGFR-2 and VEGF-2 phosphorylation at tyrosine 951 (p-VEGFR-2 (Y951)) in HUVEC infected with an adenovirus encoding sFlt-1 (sFlt1) or control virus (CMV). $\beta$-actin was used as a loading control. (c)Representative immunohistochemical staining for $\mathrm{p}$ VEGFR-2 (Y951) in gestationally-matched normal (pre-term) and preeclamptic (PE) placenta. Data are expressed as mean $( \pm \mathrm{SEM})$ or representative of three or more independent experiments performed in triplicate.

\section{Conclusions}

Endothelial cell sFlt-1 expression is regulated by VEGF and sFlt-1 is an autocrine regulator of endothelial cell function.

\section{Abbreviations}

- :

epidermal growth factor

- :

endothelial nitric oxide synthase

- :

extracellular signal regulated kinase -1/2

- :

human umbilical vein endothelial cells

- :

mitogen activated kinase

- :

nitric oxide

- :

phosphoinositide-3'-kinase

- : placenta growth factor

- :

Phosphatase and Tensin homolog deleted on chromosome Ten 
soluble vascular endothelial growth factor receptor-1

- :

vascular endothelial growth factor- $A$

$\bullet$

vascular endothelial growth factor receptor-1

- : vascular endothelial growth factor receptor-2.

\section{Declarations}

\section{Acknowledgements and funding}

This work was supported by grants from the Medical Research Council (G0600270, G0601295 and G0700288) and British Heart Foundation (RG/09/001/25940 and PG/06/114).

\section{Authors' original submitted files for images}

Below are the links to the authors' original submitted files for images.

Authors' original file for figure 1

Authors' original file for figure 2

Authors' original file for figure 3

Authors' original file for figure 4

Authors' original file for figure 5

Shakil Ahmad, Peter W Hewett contributed equally to this work.

\section{Competing interests}

The authors declare that they have no competing interests.

\section{Authors' contributions}

SA, MJC, PWH, BA, SS and TF performed the experiments and analysed the data SA PWH and MJC contributed to the writing of the manuscript. AA designed experiments and wrote the manuscript. All authors read and approved the final manuscript.

\section{References}

1. Shweiki D, Itin A, Soffer D, Keshet E. Vascular endothelial growth factor induced by hypoxia may mediate hypoxia-initiated angiogenesis. Nature. 1992;359:843-845.

View Article Google Scholar

2. Dor Y, Camenisch TD, Itin A, Fishman GI, McDonald JA, Carmeliet P, Keshet E. A novel role for VEGF in endocardial cushion formation and its potential contribution to congenital heart defects. Development. 2001;128:1531-1538.

View Article Google Scholar

3. Ferrara N, Gerber HP, LeCouter J. The biology of VEGF and its receptors. Nat Med. 2003;9:669-676. View Article Google Scholar

4. Giordano FJ Gerber HP Williams SP VanBruggen N Bunting S Ruiz-Lozano P Gu Y Nath AK Huang Y Hickey R A cardiac myocyte vascular endothelial growth factor paracrine pathway is required to maintain cardiac function Proc Natl Acad Sci USA 2001985780578533290 10.1073/pnas.091415198

5. Oosthuyse B, Moons L, Storkebaum E, Beck H, Nuyens D, Brusselmans K, Van Dorpe J, Hellings P, Gorselink M, Heymans S, et al. Deletion of the hypoxia-response element in the vascular endothelial growth factor promoter causes motor neuron degeneration. Nat Genet. 2001;28:131-138.

View Article Google Scholar

6. Storkebaum E, Lambrechts D, Dewerchin M, Moreno-Murciano MP, Appelmans S, Oh H, Van Damme P, Rutten B, Man WY, De Mol M, et al. Treatment of motoneuron degeneration by intracerebroventricular delivery of VEGF in a rat model of ALS. Nat Neurosci. 2005;8:85-92. 
7. Carmeliet P, Ferreira V, Breier G, Pollefeyt S, Kieckens L, Gertsenstein M, Fahrig M, Vandenhoeck A, Harpal K, Eberhardt C, et al. Abnormal blood vessel development and lethality in embryos lacking a single VEGF allele. Nature. 1996;380:435-439.

View Article Google Scholar

8. Ferrara N, Carver-Moore K, Chen H, Dowd M, Lu L, O'Shea KS, Powell-Braxton L, Hillan KJ, Moore MW. Heterozygous embryonic lethality induced by targeted inactivation of the VEGF gene. Nature. 1996;380:439-442.

View Article $\underline{\text { Google Scholar }}$

9. Miquerol L, Langille BL, Nagy A. Embryonic development is disrupted by modest increases in vascular endothelial growth factor gene expression. Development. 2000;127:3941-3946.

View Article Google Scholar

10. Masaki I, Yonemitsu Y, Yamashita A, Sata S, Tanii M, Komori K, Nakagawa K, Hou X, Nagai Y, Hasegawa M, et al. Angiogenic gene therapy for experimental critical limb ischemia: acceleration of limb loss by overexpression of vascular endothelial growth factor 165 but not of fibroblast growth factor-2. Circ Res. 2002;90:966-973.

View Article $\underline{\text { Google Scholar }}$

11. Vajanto I, Rissanen TT, Rutanen J, Hiltunen MO, Tuomisto TT, Arve K, Narvanen O, Manninen H, Rasanen H, Hippelainen M, et al. Evaluation of angiogenesis and side effects in ischemic rabbit hindlimbs after intramuscular injection of adenoviral vectors encoding VEGF and LacZ. J Gene Med. 2002;4:371-380. View Article Google Scholar

12. Carmeliet P. VEGF gene therapy: stimulating angiogenesis or angioma-genesis?. Nat Med. 2000;6:11021103.

View Article $\underline{\text { Google Scholar }}$

13. Lee RJ, Springer ML, Blanco-Bose WE, Shaw R, Ursell PC, Blau HM. VEGF gene delivery to myocardium: deleterious effects of unregulated expression. Circulation. 2000;102:898-901.

View Article Google Scholar

14. Springer ML, Chen AS, Kraft PE, Bednarski M, Blau HM. VEGF gene delivery to muscle: potential role for vasculogenesis in adults. Mol Cell. 1998;2:549-558.

View Article $\underline{\text { Google Scholar }}$

15. Ahmad S, Ahmed A. Elevated placental soluble vascular endothelial growth factor receptor-1 inhibits angiogenesis in preeclampsia. Circ Res. 2004;95:884-891.

View Article Google Scholar

16. Kendall RL, Wang G, Thomas KA. Identification of a natural soluble form of the vascular endothelial growth factor receptor, FLT-1, and its heterodimerization with KDR. Biochem Biophys Res Commun. 1996;226:324-328.

View Article Google Scholar

17. Park JE, Chen HH, Winer J, Houck KA, Ferrara N. Placenta growth factor. Potentiation of vascular endothelial growth factor bioactivity, in vitro and in vivo, and high affinity binding to Flt-1 but not to Flk-1/KDR. J Biol Chem. 1994;269:25646-25654.

View Article Google Scholar

18. Roeckl W, Hecht D, Sztajer H, Waltenberger J, Yayon A, Weich HA. Differential binding characteristics and cellular inhibition by soluble VEGF receptors 1 and 2. Exp Cell Res. 1998;241:161-170.

View Article Google Scholar

19. Ahmad S AA. . Regulation of soluble VEGFR-1 by VEGF and oxygen and its elevation in pre-eclampsia and fetal growth restriction. 2001;:-.

View Article Google Scholar

20. Zhou Y McMaster M Woo K Janatpour M Perry J Karpanen T Alitalo K Damsky C Fisher SJ Vascular endothelial growth factor ligands and receptors that regulate human cytotrophoblast survival are dysregulated in severe preeclampsia and hemolysis, elevated liver enzymes, and low platelets syndrome Am J Pathol 2002160140514233277330 10.1016/S0002-9440(10)62567-9 
21. Vuorela P, Helske S, Hornig C, Alitalo K, Weich H, Halmesmaki E. Amniotic fluid--soluble vascular endothelial growth factor receptor-1 in preeclampsia. Obstet Gynecol. 2000;95:353-357.

View Article Google Scholar

22. Levine RJ, Maynard SE, Qian C, Lim KH, England LJ, Yu KF, Schisterman EF, Thadhani R, Sachs BP, Epstein FH, et al. Circulating angiogenic factors and the risk of preeclampsia. N Engl J Med. 2004;350:672-683.

View Article Google Scholar

23. Ahmed A, Dunk C, Kniss D, Wilkes M. Role of VEGF receptor-1 (Flt-1) in mediating calcium-dependent nitric oxide release and limiting DNA synthesis in human trophoblast cells. Lab Invest. 1997;76:779-791. View Article Google Scholar

24. Maynard SE Min JY Merchan J Lim KH Li J Mondal S Libermann TA Morgan JP Sellke FW Stillman IE Excess placental soluble fms-like tyrosine kinase 1 (sFlt1) may contribute to endothelial dysfunction, hypertension, and proteinuria in preeclampsia J Clin Invest 2003111649658151901 10.1172/JCI17189

25. Lee S Chen TT Barber CL Jordan MC Murdock J Desai S Ferrara N Nagy A Roos KP Iruela-Arispe ML Autocrine VEGF signaling is required for vascular homeostasis Cell 20071306917033010851 10.1016/j.cell.2007.06.054

26. Bussolati B Dunk C Grohman M Kontos CD Mason J Ahmed A Vascular endothelial growth factor receptor-1 modulates vascular endothelial growth factor-mediated angiogenesis via nitric oxide Am J Pathol 2001159993 10081850457 10.1016/S0002-9440(10)61775-0

27. Tseng JF, Farnebo FA, Kisker O, Becker CM, Kuo CJ, Folkman J, Mulligan RC. Adenovirus-mediated delivery of a soluble form of the VEGF receptor Flk1 delays the growth of murine and human pancreatic adenocarcinoma in mice. Surgery. 2002;132:857-865.

View Article Google Scholar

28. Cai J, Ahmad S, Jiang WG, Huang J, Kontos CD, Boulton M, Ahmed A. Activation of vascular endothelial growth factor receptor-1 sustains angiogenesis and Bcl-2 expression via the phosphatidylinositol 3-kinase pathway in endothelial cells. Diabetes. 2003;52:2959-2968.

View Article Google Scholar

29. Bergmann A Ahmad S Cudmore M Gruber AD Wittschen P Lindenmaier W Christofori G Gross V Gonzalves A Grone HJ Reduction of circulating soluble Flt-1 alleviates preeclampsia-like symptoms in a mouse model J Cell Mol Med 2010141857 18673829045 10.1111/j.1582-4934.2009.00820.x

30. Cudmore M, Ahmad S, Al-Ani B, Fujisawa T, Coxall H, Chudasama K, Devey LR, Wigmore SJ, Abbas A, Hewett PW, Ahmed A. Negative regulation of soluble Flt-1 and soluble endoglin release by heme oxygenase-1. Circulation. 2007;115:1789-1797.

View Article Google Scholar

31. Zhou CC Ahmad S Mi T Xia L Abbasi S Hewett PW Sun C Ahmed A Kellems RE Xia Y Angiotensin II induces soluble fms-Like tyrosine kinase-1 release via calcineurin signaling pathway in pregnancy Circ Res 200710088953266823 10.1161/01.RES.0000254703.11154.18

32. Reynolds A, Leake D, Boese Q, Scaringe S, Marshall WS, Khvorova A. Rational siRNA design for RNA interference. Nat Biotechnol. 2004;22:326-330.

View Article Google Scholar

33. Ahmad S, Hewett PW, Wang P, Al-Ani B, Cudmore M, Fujisawa T, Haigh JJ, le Noble F, Wang L, Mukhopadhyay D, Ahmed A. Direct evidence for endothelial vascular endothelial growth factor receptor-1 function in nitric oxide-mediated angiogenesis. Circ Res. 2006;99:715-722.

View Article Google Scholar

34. Al-Ani B, Hewett PW, Cudmore MJ, Fujisawa T, Saifeddine M, Williams H, Ramma W, Sissaoui S, Jayaraman PS, Ohba M, et al. Activation of proteinase-activated receptor 2 stimulates soluble vascular endothelial growth factor receptor 1 release via epidermal growth factor receptor transactivation in endothelial cells. Hypertension. 2010;55:689-697.

View Article $\underline{\text { Google Scholar }}$ 
35. Huang J, Kontos CD. PTEN modulates vascular endothelial growth factor-mediated signaling and angiogenic effects. J Biol Chem. 2002;277:10760-10766.

View Article Google Scholar

36. Papapetropoulos A Garcia-Cardena G Madri JA Sessa WC Nitric oxide production contributes to the angiogenic properties of vascular endothelial growth factor in human endothelial cells J Clin Invest 1997 10031313139508526 10.1172/JCI119868

37. Murohara T Asahara T Silver M Bauters C Masuda H Kalka C Kearney M Chen D Symes JF Fishman MC Nitric oxide synthase modulates angiogenesis in response to tissue ischemia J Clin Invest 1998101 25672578508846 10.1172/JCI1560

38. Kroll J, Waltenberger J. VEGF-A induces expression of eNOS and iNOS in endothelial cells via VEGF receptor-2 (KDR). Biochem Biophys Res Commun. 1998;252:743-746.

View Article Google Scholar 